\title{
CORRIGENDUM
}

\section{Hepatocyte growth factor/scatter factor activates the ETS1 transcription factor by a RAS-RAF-MEK-ERK signaling pathway}

Rejane Paumelle, David Tulasne, Zoulika Kherrouche, Serge Plaza, Catherine Leroy, Sylvie Reveneau, Bernard Vandenbunder and Veronique Fafeur

doi:10.1038/sj.onc. 1205607

Correction to: Oncogene (2002) 21, 2309-2319.

doi:10.1038/sj.onc. 1205297

Since the publication of the above paper, the authors have identified errors in the spelling of their names and E-mail address. The correct spellings are shown on the left in each instance below:

David TULASNE not David TULASHE

Sylvie REVENEAU not Syline REVENEAU

veronique.fafeur@ibl.fr not veronique.fefeur@ibl.fr 